\title{
POST MORTEM DNA ANALYSIS FOR DETERMINATING TIME OF DEATH AND SEX IDENTIFICATION
}

\author{
Bakrey, H. H. and Nabila, M. Abed El-Aliem \\ Faculty of Vet. Med. - Department of Forensic Medicine and toxic. \\ Benha Untv., Esypl
}

\begin{abstract}
Ttme of death is usually estimated by evaluating events moslly occur after death. In this paper the potential application of ruclear DNA image analysis in tiver tissue used to evaluate post mortem interval. Afler death. internat nucleases within the cells cause degradation of nuclear DNA of hepatocyte more rapidly than other tissue, where twer cell rich in lysosomes that contain hydrolases enzymes. Nuclear DNA degradation. is measurable and quantifiable in relation to time. Thee tiver samples were taken at zero, 24, 48, 72 hours. 5 days, one and wo weeks post moriem interval. DNA ploidy. DNA index (1\&2), mean DNA content, nuclear area and DNA histogram were found to correlate with an increased post mortem interval from zero to $72 \mathrm{~h}$. Hepatocyte nucleus and sequensed DNA hislogram couldn t be detected at or more than 5 days after death. Three skeletal muscie samples (at zero, 24, 72, 1w, 2w, 19 days and 21 days) were used for sex identification using polymerase chain reaction (PCR) techntique. Sex could be identified till two weeks post mortem interval. From these results nuciear DNA in hepatocyte reveals time dependent alteration. So can be used as a predictor for post mortem interval. DNA in certein tissue (Skeletal muscle) is more siable and allowing to perform DNA typing (sex identification) by polymerase chain reaction.
\end{abstract}

\section{INTRODUCTION}

One of the most important longstanding problems in the field of forenslc medicine is the determination of the time of death (Dokgoz, et al 2001 and Johnson and Ferris. 2002). Nme of death estimated by evaluating events which happen in a deceased in conjunction with the known behavior of such cvents. The use of direct DNA testing in forenstc analysis has become increasingly common (Housman, 1995). Many recent techniques were used to monitors DNA damage induced during cell death (apoptosis. necrosis and autolysis). Comet assay isingle cell gel electrophoresis) and tumel assay are examples of these methods (Chandana, 2004, Kim, et 
al 2002 and Grasl- Kraupp, et al 1995). Moreover the probe (GACA) 4 could be used to analyse partially degraded DNA (Poche, et al 1991).

DNA founds inside and outside (mitochondria) the nucleus (Grivell, 1983 and Rush and Misra, 1985). Post mortem stability of DNA becomes an important point and has already been studied (Bar, et al, 1988; Gill, et al 1985. Hagelberg, et al, 1991 and Ogata, et al, 1990). DNA analysis have been carried out with human hard tissue and successful examinations of bones (Hagelberg , et al 1991; Jeffreys, et al, 1992 and Gill, et al 1994) and teeth (Potsch, et al 1992 and Smith, 1993 and Pfeiffer, et al, 1999) have been described. However the success of investigation depend on the degree of DNA degradation (Graw, et al 2000). DNA from brain tissue was detected even after 85 days. In heart or in muscle cells DNA were stable up to one month post mortem period allowing to perform DNA finger printing. In other tIssues (kidney. liver and lymph nodes) DNA were degraded after short period and becoming unsuitable for blotting (Bar et al 1988 and ludes, et al 1983). On the other hand under favourable conditions. successful typing is still possible after thousands of years (Hoss and Pagbo, 1993). Guality and quantity of DNA depend mainly on the type of tissue used (Bar et al, 1988 and Ludes. et al. 1993) and the site in which the body was deposited (Graw, et al 1998).

DNA typing is a useful tool in forensic for determining the remains of body who have been dead from various pertods of time, polymerase chain reaction (PCR) method gives good results (ludes, et al, 1993). DNA printing can be applied on dried blood or semen stains up to 4 years old (Gill, et al 1985).

Aim of work: the alm of this article is to use certain remained tissue (liver) for detection of post mortem interval using new quantitative measure of nuclear DNA damage. In addition to using another tissue (muscle) for DNA typing (sex identification) by polymerase chatn reaction.

\section{MATERIAL AND METHODS}

\section{Materials:}

A- Samples: Three specimen of liver and muscle $1000 \mathrm{gm}$ of each were collected from three male bull (Just after slaughtered) and brought to the laboratory in a chllled condition using liquid nitrogen. The samples are aged by keeping in the natural environment (summer) in May and June. Llver sections were taken at zero time, 24 h, 48 h. 72 h, 5 days, 7 days and two weeks to be used for determination the time of death. Sections from each muscle sample were taken at zero, 24 h. 72 h, one week, two week, 19 days and 21 days. Spectmen were kept separtely in llquid nitrogen for $1 \mathrm{~h}$. Frozen tissues stored at - 20 till examination. 


\section{Methods :}

Nuclear DNA image analysis: Five 50 un sections from each sample were put in centrifuge tubes and deparaffinized by adding $10 \mathrm{ml}$ xylene for 20 minutes and repeated twice. Sections were rehydrated using a sequence of $10 \mathrm{ml}$ of $100 \% .95 \% .70 \%$ and $50 \%$ ethanol for $20 \mathrm{~min}$ utes and each step was repeated twice. Each section washed in 2 changes of distilled water for 20 minutes and left in $10 \mathrm{ml}$ distilled water for 24 hours Bashar (1979). Then the nuclear suspension was done according to Ensley, et al (1990). The pellet was flattened on clean glass slides. The slides were atr drled then post-fixed in $10 \%$ neutral buffer formalin for 30 minutes and washed in distal water for $10 \mathrm{~min}$. and left to dried over night at room temperature.

DNA staining and analysis: Alr drled prepared slides were treated for $60 \mathrm{~min}$. in $5 \mathrm{~N} \mathrm{Hcl}$ to hydrolyze nuclear DNA. The slides stained by feulgen stain (Schulte and Fink, 1995)and analyzed with Hund CML image analyzer and soft ware (Helmut Hund Gmb HD 6330 Wetztar 21 Germany).

\section{Sex identification}

DNA extraction from tIssues: DNA was isolated from frozen tissue on three steps cell lysis. protein precipitation and DNA precipitation caccording to (Davis, 1980).

DNA primers: A set of bovine Y- chromosome specific primers (Peura et al. 1991) were used.

1- (5' primer) 1- 21: 5' - GGA TCC GAG ACA CAG AAC AGG - 3.

2- (3' primer) 1 - 21: 5' - GC TAAT CCA TCC ATC CTA TAG - 3:

Oligonucleotide primers dissolved in 10 mM tris $\mathrm{Hcl}$ and ImM EDTA (PH 8.0) TE buffer.

PCR reactions: The reactions were carred out as described by Saikd et al. (1988). The reactions were conducted by using Master mix (50 ng DNA as a template. The reaction mixture contained $5 \mathrm{ul}$ of $10 \mathrm{X}$ buffer, $0.4 \mathrm{ul}$ of taq DNA polymerase, $200 \mathrm{uM}$ of dNTPS) and 20 pmol of each primer. The amplifications were carrled out in Gene AMP PCR system 9700.

\section{Analysis of the amplified product:}

Products were analysed by agarose gell electrophoresis according to the method described by (Sambrook, et al 1989). The gel was examined under ultraviolet light as ethidium bromide intercalate between the bases of the DNA and will fluoresce. Photographs were taken.

N.b. Marker give different bands each 50 base pair. 
The data were calculated as mean \pm stander error by the student's ( $t$ ) test "statase" programe.

\section{RESULTS}

Cytometric parameters of nuclear DNA analysis were cleared in table (1). Such table showed that the stemline ploidy $I$ and DNA Index (content) $I$ were $2 \pm 0.4$ and $1 \pm 0.2$ at zero time. $1.29 \pm$ 0.3 and $0.64 \pm 0.1$ at $24 \mathrm{~h}, 0.87 \pm 0.2$ and $0.43 \pm 0.1$ at $48 \mathrm{~h}$ and $0.69 \pm 0.2$ and $0.34 \pm 0.1$ at $72 \mathrm{~h}$ post mortem interval and not recorded at 5 days, one and two weeks respectively where there is no cells could be seen. Decrease at $48 \mathrm{~h}$ and $72 \mathrm{~h}$ is signilicant in relation to zero time. Stemline plotdy 2 and DNA index 2 were $4.07 \pm 0.2$ and $2.04 \pm 0.1$ at zero time. $3.61 \pm 0.8$ and $1.81 \pm 0.4$ at $24 \mathrm{~h}, 1.88 \pm 0.4$ and $0.94 \pm 0.2$ at $48 \mathrm{~h}$, post mortem interval (significant decrease at $48 \mathrm{~h}$ was detected). Mean DNA contents were $2.86 \pm 0.37,1.91 \pm 0.15,1.36 \pm 0.3$ and $1.13 \pm$ 0.15 at zero, $24 \mathrm{~h}, 48 \mathrm{~h}$ and $72 \mathrm{~h}$ respectively which indicat significant decrease and not recorded at 5 days, one \& two weeks. Mean area of nuclet were $36.93 \pm 2.3 .48 .78 \pm 0.7 .23 .02 \pm 2.8$ and $16.18 \pm 3.5$ micron at zero, $24 \mathrm{~h} .48 \mathrm{~h}$ and $72 \mathrm{~h}$ post mortem Interval. All data showed significant decrease except at $24 \mathrm{~h}$ showed signifcant increase However these data not recorded at 5 days. one and two weaks post mortem interval. These data were cleared in fig 1, 2, 3, 4, 5 and 6 (A and $B)$.

DNA histogram was considered diplold when peak occupled the diplold position $0.9-1.1$ (normal DNA indx I) or at $1.9-2.1$ (normal DNA index 2) and less than $15 \%$ of cells were present at an euplold position. The aneuplold postitions means peak occupled position more or less than $0.9-1.1$ or $1.9-2.1$. The term aneuploid is used to describe hypodiplotd. hyperdiplosd and hypertetraplold.

DNA histograms at zero time and $24 \mathrm{~h}$ post mortem interval considered diplold, where peaks occupled the position (1.9-2.1) and (0.9-1.1) respectlvely. At $48 \mathrm{~h}$ the histogram shifted to left and the cases is aneuploid (hypodiploid). At $72 \mathrm{~h}$ the histogram is completely shifted to right and the cases is aneuploid (hypodiplold)

Figure 7 and 8 showed results obtained for sex identiflcation by polymerase chaln reaction after zero, 24, 72h, 1 w, 2 w, 19 days and 3 weeks post mortem interval from muscle of male bull. Discrete 300 dip band was observed in lanes 1, 2, 3 (zero time) 4, 5, 6 (24h) 7, 8, 9 (72h) 10 , 11 and no band at lane 12 ( 1 w) 13, 14 while no band at lane 15 ( 2 w). While no sex spectic bands were seen at lane 16, 17, 18 (19 days) and lane 19,20,21, 22 (3 week) post mortem intervale. 


\section{DISCUSSION}

There are multiple reasons for trying to estimate accurate time of death. As it important to law men. Also may help in assessing whether a proposed cause of death is reasonable. Development of techniques for measuring the quantity of nuclear DNA in apopulation of cells resulted in refinement of prognostic criteria (look et al, 1985). One of such techniques is the DNA Image cytometry. Nuclear DNA fragmentation may be a post mortem consequence of DNA fragility (Grasl- Kraupp, et al 1995 and Schallock, et al. 1997). Studies of nuclel extracted fron tissuc (Ilver) at different post- mortern Ume and analysed by image analysis provided knowledge of prognostic value of measuring DNA content. Data of table (1) showed that stem tine ploidy 1 and 2 and related DNA content $I$ and 2 in addition to mean DNA content were decreased as time post mortem interval increased. Mean area of nuclei showed the same relation with exception at $24 \mathrm{~h}$ post mortem which increased. These results agree with Bar, et al (1988) and Ludes, et al, (1993). They recorded that DNA from tissue (liverl were degraded after short peroid of death and becoming unsultable for blotting. Also agree with Genest, et al (1992) who recorded that at least $1 \%$ of nuclear basophilla thematoxylin staining of nucleoprotein of cell) loss in hepatocytes at 24 hours or more after death. and all nuclear basophilia loss at 96 hours or more post mortem interval. Also Jenner and Hirsch (2000) detected disappearance of nuclear basophlia in fetal organs during death process.

These results may be explained as a result of postmortem decay which beginning with autolysis and followed by aerobic and bacterial decomposition of organic material. Autolysis (non bactertal autodigestion) occur by enzymes liberated from lysosomes (hydrolases eniymel (Derzeltod, 1955 and Gossner, 1955]. DNA in dead cells is degraded by nucleases which belong to hydrolases enzyme that includes endonucleases and exonucleases. Liver cells contain large number of lysosmes (Grasl- Kraupp, et al 1995).

Nuclear DNA not detected at or more 5 day postmortem as clear in table (11) and Fig. (5 and 6). These results are some what disagree with Bar, et al (1988) who recorded complet degradation of DNA in liver cells varled from $24-36 \mathrm{~h}$; while ludes et al (1993) reported that yield of DNA becoming very low beyond aperoid of one week after death. Such variations may be explained as degraded DNA correlated to many factors as environmental $T$... at the site of death and for infections diseases prtor to death (Bax et al, 1988). Also damp condition can cause rapid degradation of DNA (Graw, et al 2000).

Area of nuclet correlated directly with the duration of post mortem peroid as in table (1) and Fig. (1, 2. 3 and 4). This result may be explained as when cell dies, the PH lowers, lysozyme (an enzyme within cell) is activated, and the nuclear matter disintegrates and loss of nuclear sub. 
stance occure (Jenner and Hirsch, 2000). Also partlaly agree with Trump, et al (1965) who observed pale nuclear chromation and indistinct out line in liver tissue incubated at $37^{\circ} \mathrm{C}$.

Hepatocyte as clear in fig. (1, 2, 3, 4 and 5) showed sequense changes espectaly in nuclei and cell outline. These changes were correlated directly with the duration of the post mortem peroid. These results agree with Tateyama et al. (1998) and Trump, et al (1965). They found that tissue removed from body and left unfixed undergo coagulative necrosis. The cell show slightly eosinophilic cytoplasm with little or no alteration of cellular detalls in early phase. As necrosis progresses the dead cell swollen and the nuclel become indisunct. Cellular fragmentation occur resulting from degenerative changes of autolysis.

In the present study DNA Image cytometry of the smaples at zero and $24 \mathrm{~h}$ post mortem Interval showed non aneuplold (diploid) histograms. At 48 and $72 \mathrm{~h}$ post time interval DNA index is aneuploid (hypodiploid) and DNA histograme become shifted to left. These results suggests that internucleosomal DNA cleavage progresses a ccording to time (Tateyama, et al 1998), where intracellular $\mathrm{Ca}^{2+}$ concentration elevates after degradation of cell membrane (Farber, 1982). This process could be followed by random cleavage of DNA medlated by released lysosomal enzymes.

Fascinating reports about DNA recovery from Egyptian mummles gave rise to interesting speculations (Paabo, 1985 and Margaret and Jones, 1986). DNA was recoverd from skeletal muscle at different time post mortem interval (zero, 24h, 72h, one week, two weeks, 19 days and three weeks) showed discrete bands in lanes corresponding to reactions performed at zero. $24 \mathrm{~h}$. $72 \mathrm{~h}$, frst and second samples at one week and two weaks post mortem interval. No bands were seen in samples obtained at 19 days and three weeks after death.

This result partlaly egree with Gill (1987), Bar et al (1988) and ludes, et al (1993). They recorded good DNA stability in brain and muscles over aperoid of three weeks post mortem allowIng to perform DNA finger printing. Our results were incomplet agree with those authors due to their samples was kept at different T... from 5 to $25^{\circ} \mathrm{C}$. So DNA could be detected for up to 3 weeks while our samples kept in open environment (in summer), where To reach $35^{\circ} \mathrm{C}$ or more. High environmental To at the site of death were the main factor for rapid autolysis (Bar, et al 1989). Fragementation of DNA by non specific hydrolysis affected primarly the longer fragment which were better target than the shorter fragment. This hydrolysis produced polynucleotides shorter and never of identical length. Complete loss of high molecular weight DNA never showed banding patterns after hybridisation (Bar et al, 1988). Also Wiegand, et al, (1992) mentioned that environmental condition reduce the chances of success after short time of death.

Conclusion: DNA nuclear changes in tissues at different time of death is important point that need to be studied in relation to environmental condition. Some tissue (liver) found to be suitable 
for detection of post mortem interval because rapid degradation of DNA. Other tissues as skeletal muscle found to be good suilable for DNA finger printing. Nuclear DNA image analysis offer significant improvement in monitoing the kinetics of DNA fragmentation induced during cell death coupled with its simplicity and the ability to detect responses of small cell subpopulation this method has a rellable and sensitive analysis of cell death.

Table (1): Cytometric parameters of nucleur DNA image analysis according to post mortem interval. (Mean \pm S.E.).

\begin{tabular}{|c|c|c|c|c|c|c|c|}
\hline \multirow[b]{2}{*}{$\begin{array}{l}\text { Cytometric } \\
\text { Parmeters }\end{array}$} & \multicolumn{7}{|c|}{ Time post mortem interval } \\
\hline & Zero & $24 \mathrm{~h}$ & $48 \mathrm{~h}$ & $72 \mathrm{~h}$ & $\begin{array}{c}5 \\
\text { day }\end{array}$ & $\begin{array}{c}\text { One } \\
\text { weeks }\end{array}$ & $\begin{array}{l}\text { Tivo } \\
\text { weeks }\end{array}$ \\
\hline Stemline ploidy (1) & $2 \pm 0.4$ & $1.29 \pm 0.3$ & $0.87^{\star} \pm 0.2$ & $0.69 * \pm 0.2$ & . & - & . \\
\hline DNA index (I) & $1 \pm 0.2$ & $0.64 \pm 0.1$ & $0.43^{*} \pm 0.1$ & $0.34 * \pm 0.1$ & & & \\
\hline Stemline ploidy (2) & $4.07 \pm 0.2$ & $3.61 \pm 0.8$ & $1.88^{* *} \pm 0.4$ & . & - & - & - \\
\hline DNA index (2) & $2.04 \pm 0.1$ & $1.81 \pm 0.4$ & $0.94 * * \pm 0.2$ & - & $\dot{-}$ & - & 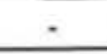 \\
\hline $\begin{array}{c}\text { Mean of DNA } \\
\text { content }\end{array}$ & $2.86 \pm 0.37$ & $1.91^{* *} \pm 0.15$ & $1.36 * \pm 0.3$ & $1.13^{* *} \pm 0.15$ & - & - & - \\
\hline $\begin{array}{c}\text { Mean area of nuclei } \\
\text { (micron) }\end{array}$ & $36.93 \pm 2.3$ & $48.78 \pm 0.7$ & $23.02 * \pm 2.8$ & $16.18^{* *} \pm 3.5$ & $\cdot$ & - & - \\
\hline
\end{tabular}

* Significant at $p \leq 0.05$

** High significant at $p \leq 0.01$ 

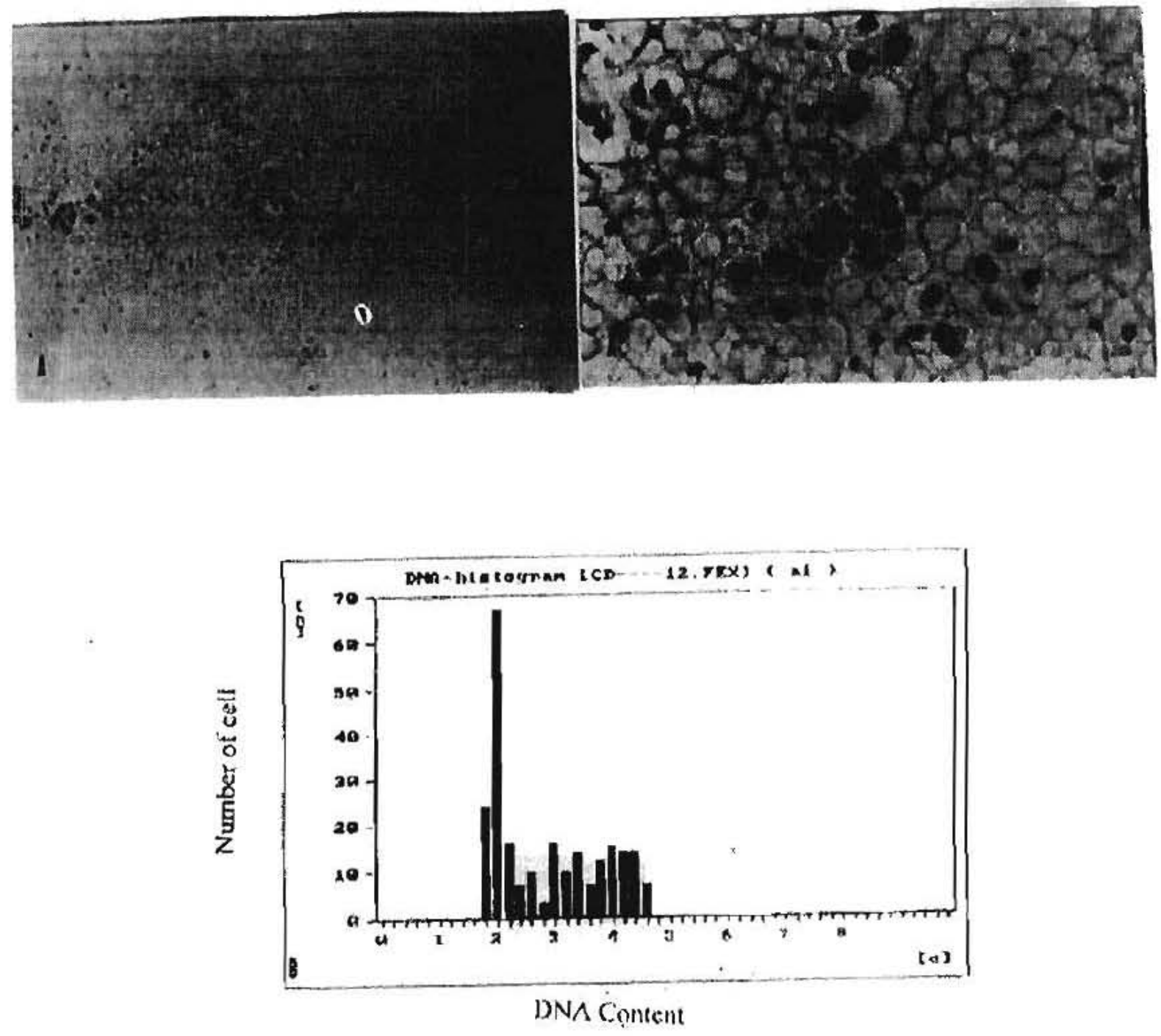

Fig. 1 A) Hepatocyte Showed no alteration of cellular detall nueleus at zero time post mortem interval (Feulgen's stain). $\times 150$ and $\times 600$.

B) DNA histograme at zero time post mortem interval showing normal diploid peak usIng DNA Imaging cytometer. 

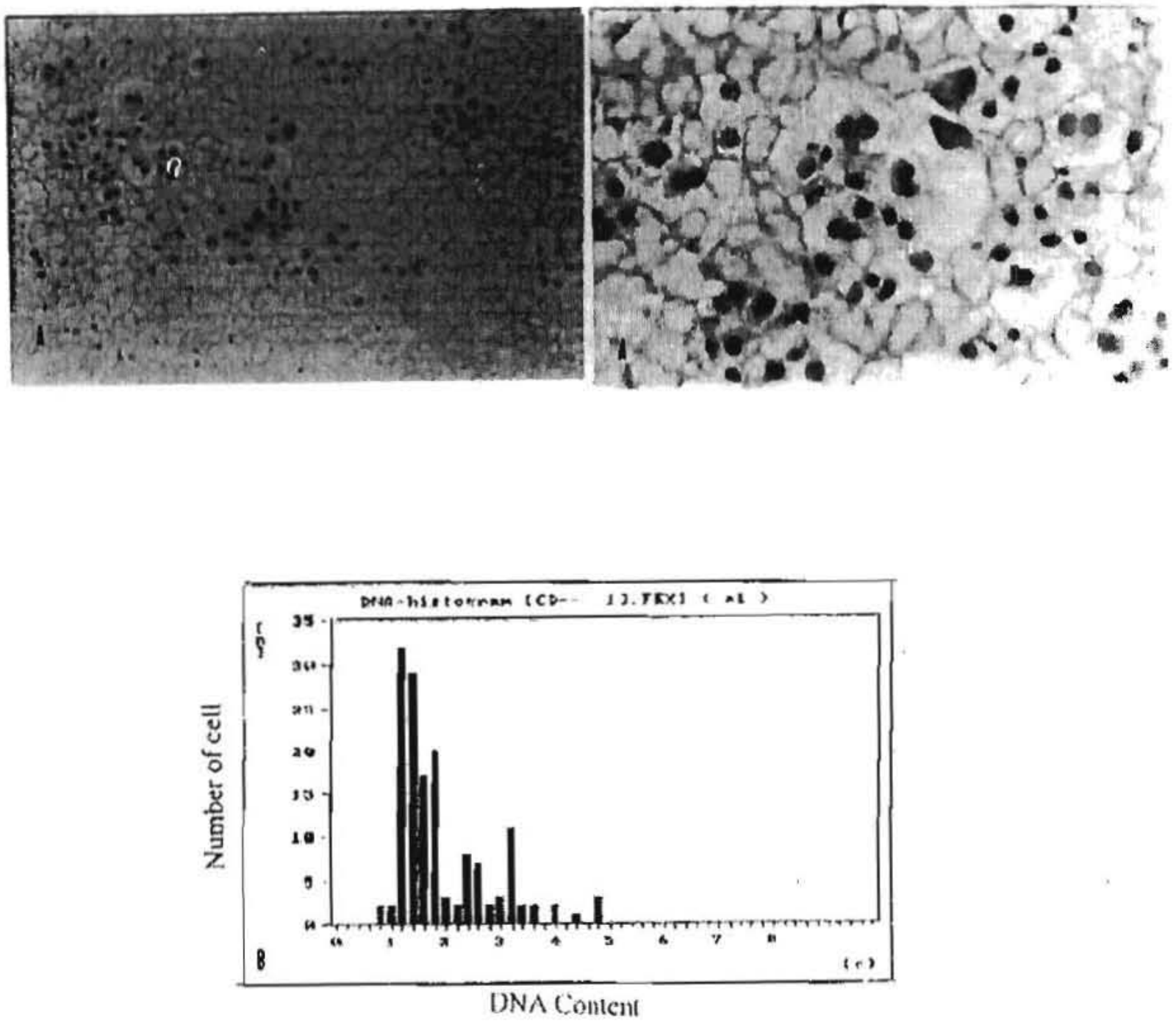

Fig. 2 A) Hepatocyte Showed eosinophilic cytoplasm with little swollen of nueleus at 24 h post mortem interval (Feulgen's stain). X 150 and X 600 .

B) DNA histograme at $24 \mathrm{~h}$ post mortem interval showing nearly diploid peak using DNA imaging cytometer. 

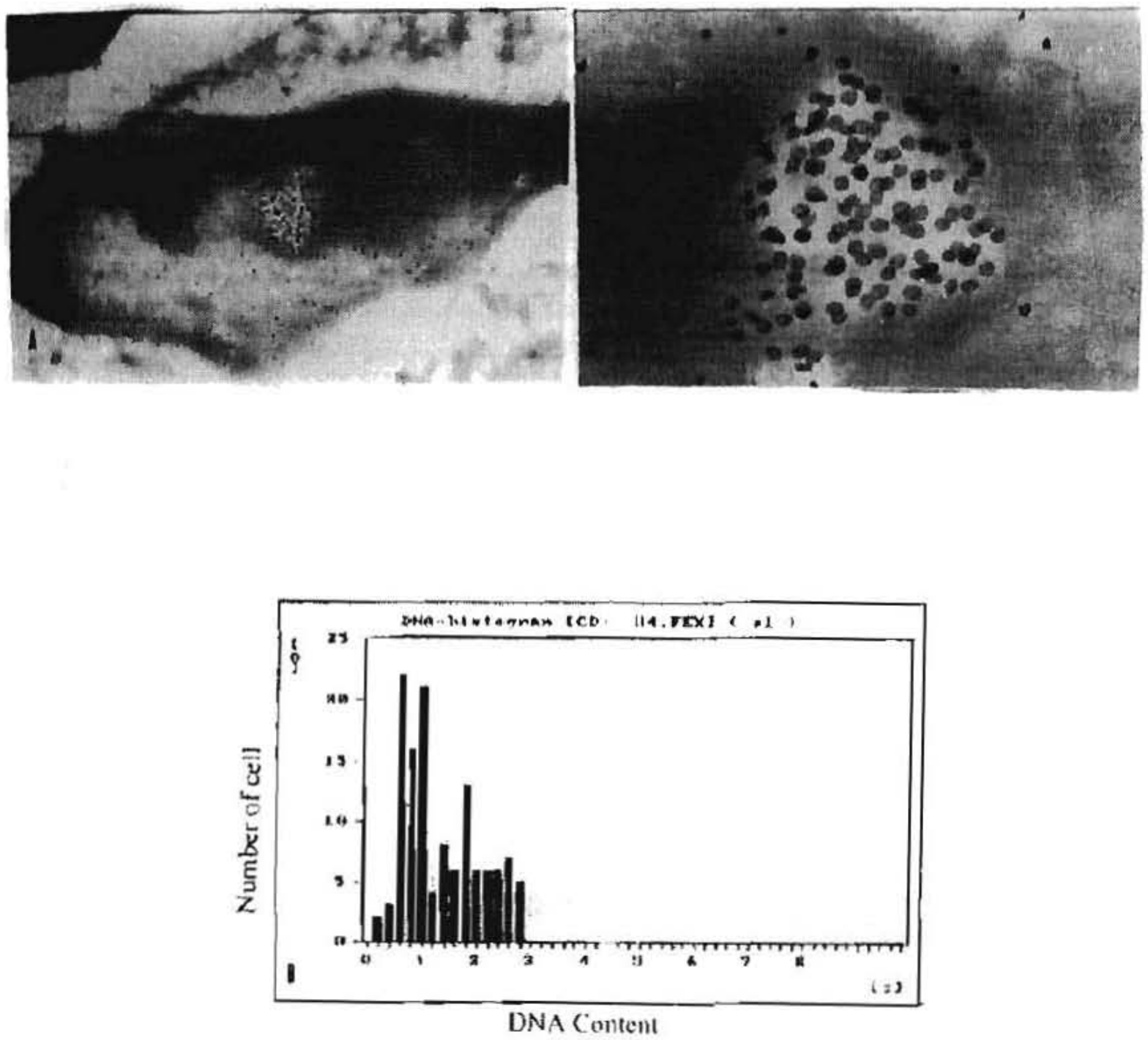

Fig. 3 A) Hepatocyte at $48 \mathrm{~h}$. are swollen and som nuclel become indistinct with little preservation of cell out line at $48 \mathrm{~h}$ post mortem interval (Feulgen's stain).

B) DNA histograme of hepatocyte nuclus at $48 \mathrm{~h}$ post mortem interval showing aneuploid pcak using DNA imaging cytometer. 

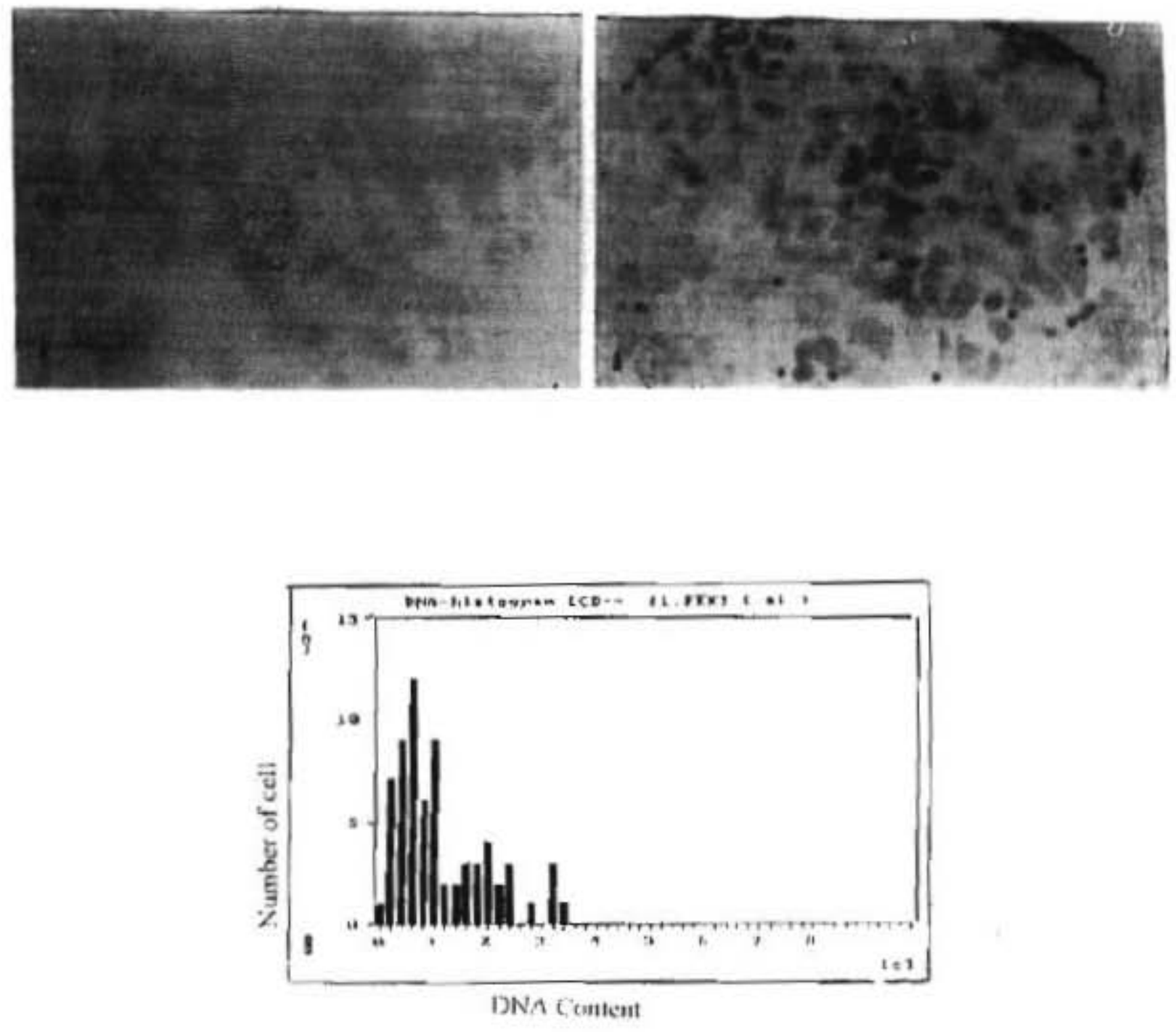

Fig. 4 A) Hepatocyte at $72 \mathrm{~h}$. are swolien and becone indistinct with out preservation of cell out line (Feulgen's stain). X 150 and X600.

B) DNA histograme of hepatocyte nuclus at $72 \mathrm{~h}$ post mortem interval showing aneuploid peak using DNA imaging cylometer. 


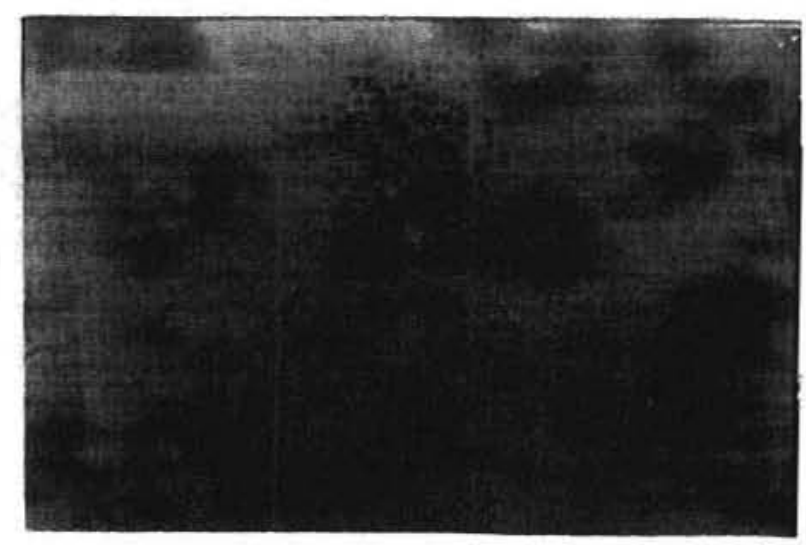

Fig. 5 : Hepatocyte showed cellular fragmentation at 5 days post mortem interval (Feulgen's stain). X 150.
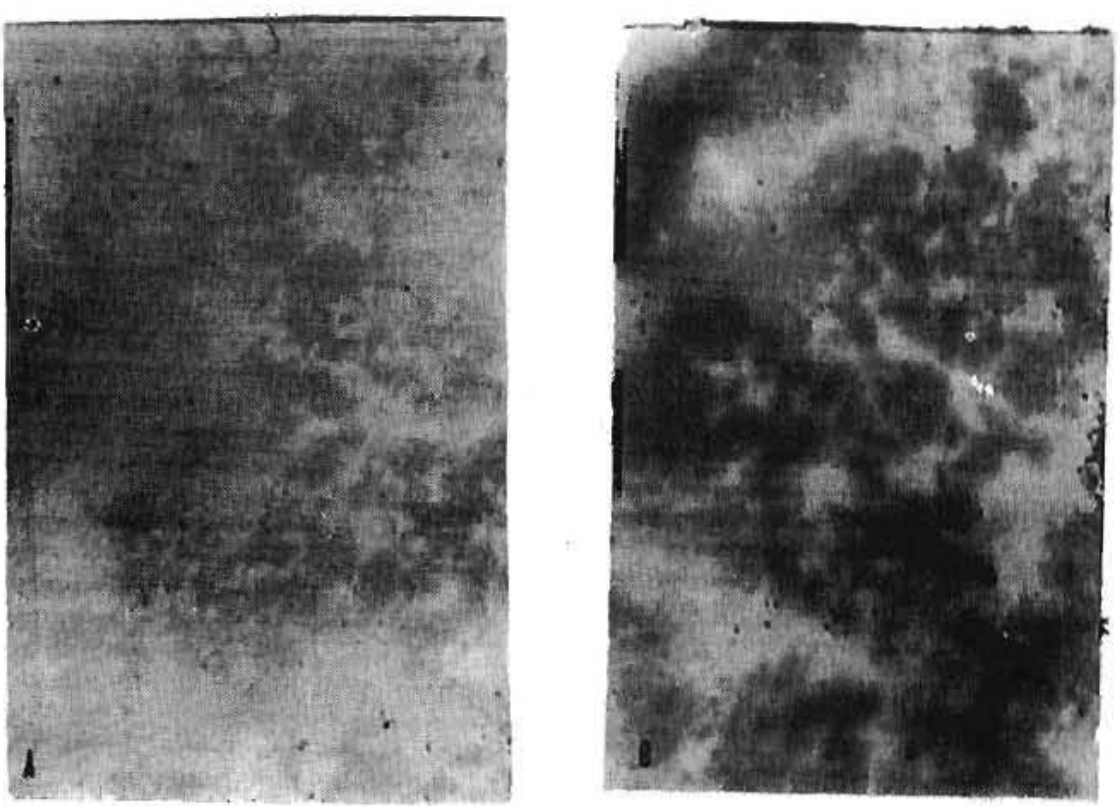

Fig. 6 : Liver tissue at 7 days $(A)$ and 2 weeks $(B)$ post mortem interval showed non identilied cell or nucleus [Feulgen s stain). no DNA histogram couid be obtained. X 150.

Mansoura, Vet. Med. J.

Vol. VII, No. 1, 2005 
Bakrey, H. H. and Nabila, M. Abed EI-Aliem

Fig. 7) Banding patteren of $\mathrm{Y}$ chromosome - specific sequences in $1.4 \%$ agarose gelelectrophoresis of male bull at zero Dane 1, 2, 3), 241 liane 4,5. 6). 72 (lane $7,8,9)$ and I $w$, lane 10 and 1 post mortern Interval. Lane (M) contains DNA marker.

Fig. 8) Banding pafteren of $Y$ chromosome - spectfle sequences of male bull at one weeks flane 12). two weeks (lane 13. 14. 151. 19 days flane 16. 17, 181 and 21 days (lane 19. 20, 21. 22) post mortem interval. Lane (M) contain DNA marker.
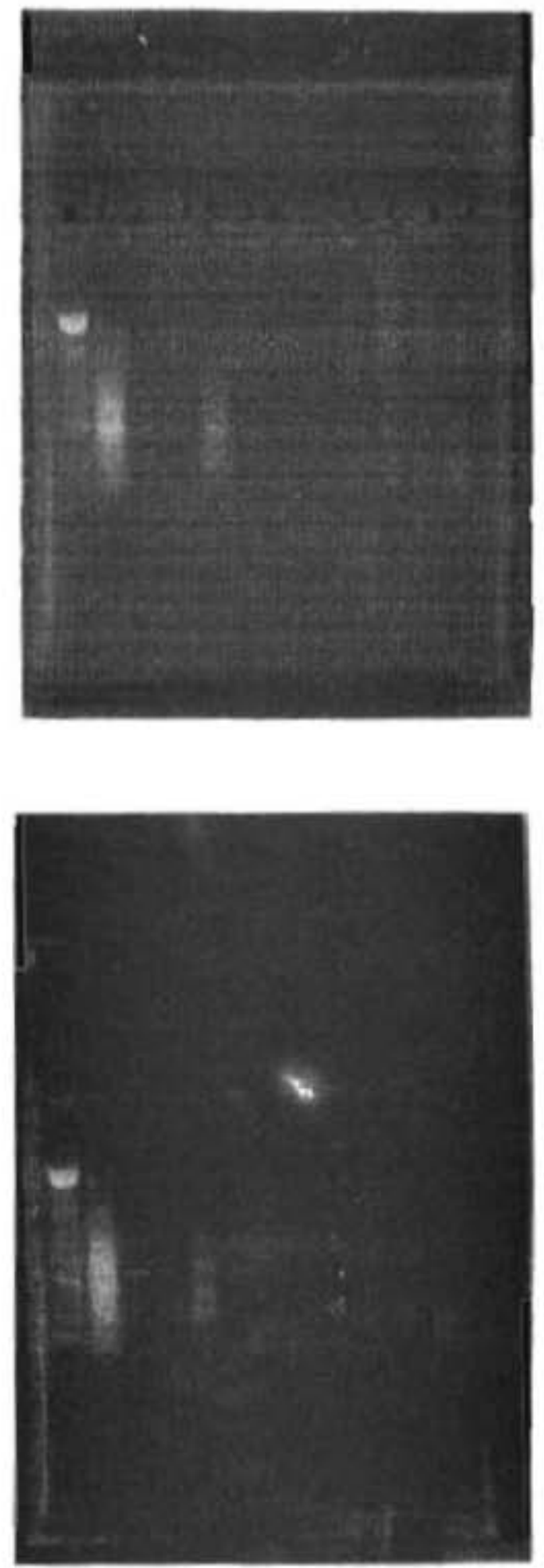

Mansoura, Vet. Med. J. 


\section{REFERENCES}

Bar, W.: Kratzer, A.; Machler, M. and Schmld, W. (1988) : "Post mortem stability of DNA" Ferensic Sclence International, 39: 59 - 70.

Bashar, M.M. (1979): Dispersion and tissues. Meth. Enzymol.. 58: $119-131$.

Chandana, s. (2004) : Single cell gell electrophoresis assay monitors precise kinetics of DNA fragmentation induced during programed cell death. Cytometry 61 (2): 127.

Davis, R. W. (1980) : Rapld DNA isolation for enzymatic and hyperdization analysis. Methods in Enzymology. 65: $404-411$.

Derzeltod, M. E. (1955) : Hdd Allg path $11 /$ I, H.W. AJtmann, Springer-verlag, Berline, Gottingen. Heide- Lberg p. 613.

Dokgoz, H.; Artcan, N.; Elmas, I. and Fincanci, S. K. (2001) : Comparison of morphological changes in white cells after death and in vitro storage of blood for the estimation of post - mortem interval. Forensic Sc1. Int. 15, 124 (1): 25 - 31.

Ensley, J.: Alonso, M.: Maclorowshi, Z. and petraszkiewiez, H. (1990) : Comparison of DNA content parameters in paired pre-treatment blopstes (PTB) and surgical resection [SR] of squamous cell carcinoma of the head and neck (SCCHN). Proc. AACR. 24:31.

Farber, J.L. (1982) : Membrane infury and calcium homeostasis in the pathogenests of coagulative necrosis. Lab Invest. 47: 114 - 123.

Genest, D. R.: Wllliams, M. A. and Greene, M. F. (1992) : Estimating the time of death in still born fetuses: I. Histologic evaluation of fetal organs; and autopsy study of 150 stillborns. Obstet Gynecol., 80: 575 - 584.

Gil, p. (1987) : A new method for sex determination of the doner of forensic samples using a recombinant DNA probe Electrophoresis. 8: 35 - 38 :

Gill, P.: Jeffreys, A. J. and Werret, D. J. (1985) : "Forensic application of DNA fingerprints". Nature 318: 577 - 579 .

Electrophoresis, 8: $35-38$.

Gill, P.: Ivanov, P. L., Kimplon, C.; Plexcy, R., Benson, N.; Tully, G. Evett, . and Hagelberg. B. K. (1994) : Identincation of the remains of the Romanov family by DNA analysis. Nat. Genet. 6: $130-135$.

Gossner, W. (1955) : Untersuchungen uberdas verhalten der phosphatasen und Esterasen wahrend der Autolyse. Virchous Arch. 327: 304. 
Grasl- Kraupp, B.; Ruttkay - Nedecky. B.; Koudelka, H.; Bukowska. K.: Bursch, W. and Hermann, s. R. (1995) : In situ detection of fragmented DNA (TUNEL. Assay) falls to discriminate among apoptosis. necrosis and autolytic ccll death: Acautionary Note. Hepatology. $1465-1468$.

Graw. M.: Weisser, J. H. and Lutz, S. (2000) : DNA typing of human remains found in dainp environments. Forensic science international. 113:91-95.

Graw, M.; Welsser. J. H.; Lutz, S. and Haffner, H. T. (1998) : DNA typling of forensic skeletal remains proceedings 2. European symposium on Human Iclentification. Promega Madison. P. 148

Grivell, L. (1983) : Mitochondrial DNA. Sci. Am. 225: $78-89$.

Hagelberg. E.: Gray, I. C. and Jeffreys. A. J. (1991): Identification of the skeletal remains of a murder victum by DNA analysis. Nature $352: 427-429$.

Hoss. M. and Paabo, S. (1993) : DNA extraction from pletstocene bones by a silica-based purifcation method. Nucl. Acid Res. 21: 3913 - 3914.

Housman, D. E. (1995) : DNA on trial - The molecular basis of DNA fingerprinting. The New England Journal of Medicine, 332 (8): 534 - 535 .

Jeffreys, J. A.; Allen, J. M. Hagelberg, E. and Sonnberg, A. (1992) : Idientification of the skel. etal remains of Josef Mengele by DNA analysis, forcnsic Scl. Int. 56: 65 - 76.

Jenner, K. R. cnd Hirsch E. B. (2000) : Determining the timeing of fetal cieath. Freensan and Jenner, P.C. 3 Bethesda, Maryland 20814.

Johnson, L. A. and Ferris, J. A. (2002) : Analysis of post mortem DNA degradation by single -cell gel electrophoresis. Forensic Scl. Int. 28, 126 (1): $34-47$.

Kim, D. S.; park, J. J.: Edler, L.; von fournier, D.; Haase, W.: Sautter- BihI. M. L.; Gotzes. F. and Thielmann, H. W. (2002) : New measure of DNA repalr in a single cell gel electrophoresis. Comet assay. Environ, Mol. Muta: 40 (1): 50 - 56 .

Look, A. T.; Roberson, B. K. and Willams, D. L. (1985) : Prognostic importance of blood cell DNA content in childhood acuite lymphoblastic leukemla. Blood 65: 1079 - 1086.

Ludes, B.: Pritzinger, H. and Mangin, P. (1993) : DNA fingerprinting from tissues after variable postmortem periods. Journal of forensic sclences. 38 (3): 686 - 690 .

Margarct, A. H. and Jones, D. S. (1986) : Body in the bog but no DNA. Nature, 323: 208.

Ogats, M.; Mattern, R.; Schneider, P. M.; Schaker, U.; Kaufmann, T. and Rittner, C. (1990) 
: Quantitative and qualitative analysis of DNA extracted from post mortem muscle tissue. Zeitschrift fur Rechtsmedizln, 103: 397 - 406.

Paabo, S. (1985) : Molecular cloning of ancient egyption mummy DNA. Nature, 314: 644 - 645.

Peura, T.; Hyttinen, J. M.; Turunen, M. and Janne, J. (1991) : Theriogenology, 35 (3): 5 - 7.

Pfelffer, H.; Huhne, B.; Seitz, B. and Brinkmann, B. (1999) : Influence of soll storage and exposure pertod on DNA recovery from teeth. Int. J. legal Med. 112: 142 - 144.

Poche, H.: Peters, C.; Worbel, G.: Schneider, V. and Epplen, J.T. (1991): Determining consanguinity by oligonucleotsde fingerprinting with (GTG)5 (CAC)5 Electrophoresis: 12 (6): $397-402$.

Potsch, L.; Meyer, U.: Rothschlld, S.; Schneider, P. M. and Rittner, C. (1992) : Application of DNA techniques for Identification using human dental pulp as a source of DNA. Int. J., legal Med. 105: 139 - 143 .

Rush, M.G. and Misra, R. (1985): Extrachromosomal DNA in eukaryotes. Plasmid 14: 177 . 191.

Saiki, R. K.; Gelfand, D. H.; stoffel, S.; Scharf, S. J.; Higuchi, R.; Horn, G. T.; Mullis, K. B. and Erlich, H. (1988) : Science 239, 487.

Sambrook, G.; Fritoch, E. M. and Manialia, T. (1989) : Agarose gel electrophoresis in molecular coining: A laboratory manual. 2nd Ed. Cold Spoog Harber laboratory. Cold Spoog Harber New York. $6.3-6.23$.

Schallock, K.; Schulz - Schaeffer, W.J.; Giese, A.; kretzschmar, H. A. (1997) : Postmortem delay and temperature conditions affect the in situ end-labeling assay in brain tissue of mice. Clin neuropathol. 16: $133-136$.

Schulte, E. K. and Fink, D. K. (1995) : Hematoxylin staining In quantitative DNA cytometry: an Image analysis study. Anal. Cell pathol. 9 (4): 257 - 268.

Smith, B. C.; Fisher, D. L.; Weedn, W. V.; Warnock, R. G. and Holland, M. M. (1993) : Asystematic approach to the sampling of dental DNA. J. Forensic sci. 38: $1194-1209$.

Tateyama, H.: Tada, T.; Haltori, H.; Murase, T.; L1, W. and Eimoto. T. (1998) : Effect of prefixation and fixation times on apoplosis detection by in situ end- labeling of ragmeuted DNA. Arch. Pathol. Lab. Med. 122: 252 - 255.

Trump. B. F.; Goldblatt, P. I.; Stowell, R. E. (1965) : Studles of mousc liver necrosis in vitro: ultrastructural and cytochemical alterations in hepatic parenchymal cell nuclei. Lab. 
Bakrey, H. H, and Nabila, M. Abed El-Aliem

Invest. 14: $1969-1999$.

Wiegand, P.; Rand, S. and Bajanowski, T. (1992) : Moglichkeften der DNA - typisierung an exhumierten leichenge weben, Rechtsmedizin. 3: 10-13.

Acknowledge:

To all staff members of clinical pathology dep. and early cancer detection unit. Zagazig university for their help in performing practical parts. 


$$
\text { المخص العربى }
$$

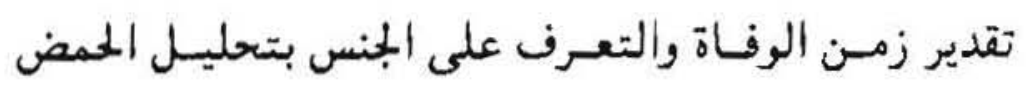

$$
\begin{aligned}
& \text { النووى الديزوكس ريبوزى بعد النفوق } \\
& \text { حاتسم حســين بكرى بيله محمبرد عبدالعليم } \\
& \text { كلبة الطب البيطرى - تسم الطب الشرعى والسعوم - بامعة بنها }
\end{aligned}
$$

يقدر الوقت الذى مضى على حدوث الوفاة بتفبيم حقانق غالبا ماتحدث بعد الوفاة، فى هذا لبحث يدرس إمكانية

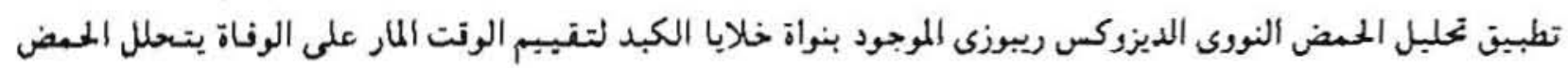

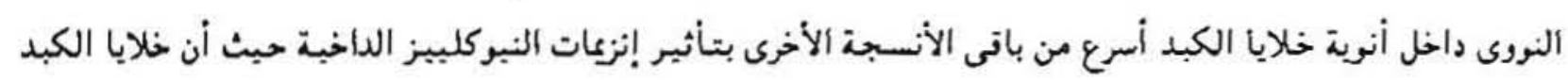

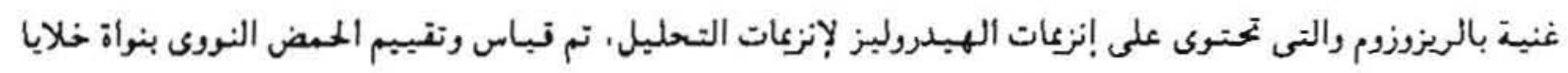

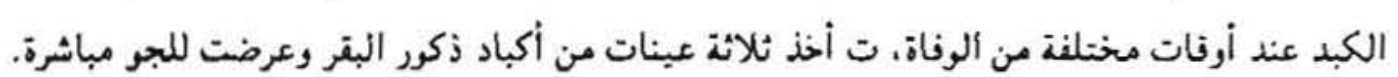
ثم أخذت عبنات بعد الوفاة مباشرة من هذه الاكباد ثم عند ع , YA , YY ساعة، O أبام، إسبوع وإسبوعين بعد الوفاة

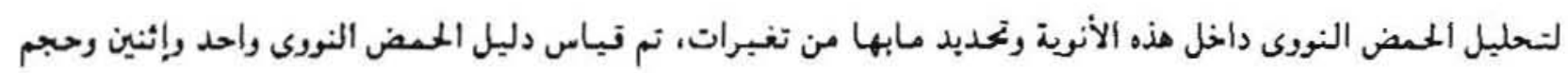

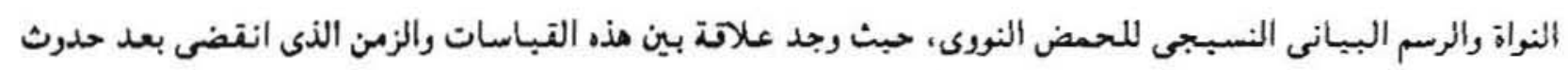

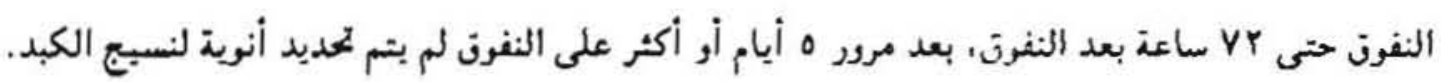
أخذت ثلاث عبنات من عضلات نفس الحيرانات السابقة وعرضت للجو مباشرة وتم أخذ ثلاث عينات عند نترات

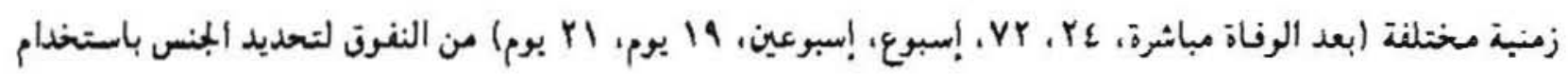

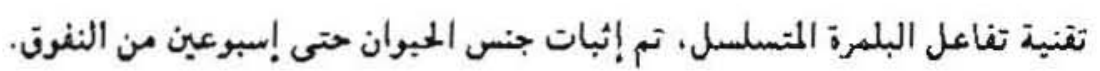
ونخلص من تلك الدراسة بإمكانية تقدير الوتت المار على النفرن بتسجبل التغبر الحادث للحسض النورى داخل أنوية

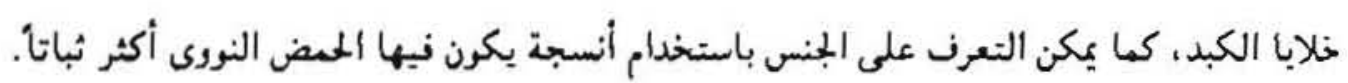

